\title{
Securing Sovereignty by Governing Security through Markets
}

\author{
Leander, Anna
}

Document Version

Final published version

Publication date:

2007

License

CC BY-NC-ND

Citation for published version (APA):

Leander, A. (2007). Securing Sovereignty by Governing Security through Markets. Department of Intercultural Communication and Management, Copenhagen Business School.

Link to publication in CBS Research Portal

\section{General rights}

Copyright and moral rights for the publications made accessible in the public portal are retained by the authors and/or other copyright owners and it is a condition of accessing publications that users recognise and abide by the legal requirements associated with these rights.

\section{Take down policy}

If you believe that this document breaches copyright please contact us (research.lib@cbs.dk) providing details, and we will remove access to the work immediately and investigate your claim. 


\title{
Copenhagen Business School
}

\author{
HANDELSHøJSKOLEN
}

\author{
Department of \\ Intercultural Communication and Management \\ Porcelænshaven 18 \\ DK-2000 Frederiksberg
}

Anna Leander

Associate Professor

ale.ikl@cbs.dk 


\section{Securing Sovereignty by Governing Security through Markets}

By Anna Leander

Hansewissenschaftskolleg Delmenhorst and Copenhagen Business School, IKL.

Draft of a Contribution to

Rebbecca Adler-Nissen and Thomas Gammeltoft-Hansen (eds)

"Sovereignty Games: Instrumentalising State Sovereignty in Europe and Beyond"

Presented at

- The COSTA24 seminar on the private construction of threats (Basel 20 October 2007)

- The fellow-seminar at the Hansewissenschaftskolleg (17 October 2007),

- The DIIS “markets for peace” workshop (6-7 December 2007) 


\section{Securing Sovereignty by Governing Security through Markets $^{1}$}

Anna Leander

On September 162007 the employees of the U.S. security firm Blackwater became involved in a shooting incidence in the Nisour Square in Baghdad. They were escorting a U.S. State Department delegation, which according to the firm, came under attack. According to by-standers, the Blackwater employees opened fire unprovoked, shooting in all directions and seemingly at anyone moving, including those trying to flee or help those wounded. 17 Iraqis civilians died in the incidence and at least twice as many were wounded. President Al-Maliki immediately came out to "revoke Blackwater's license" for operating in Iraq and Iraqi authorities engaged the process of ending contractor impunity in their country. However, it soon became clear that there was no license to revoke and that the Iraqi government may not have the authority to deny Blackwater the right to operate in Iraq, let alone decide the fate of private contractors more generally. On their part, the U.S. authorities promised to open their own investigation and expressed regret at the civilian casualties but did not end their contracts with Blackwater in Iraq or elsewhere. ${ }^{2}$ The incapacity of the Iraqi government to impose its authority and right to control the use of force on its territory, to hold Blackwater and/or its employees accountable for the incidence, made Jeremy Scahill ${ }^{3}$ conclude that: "nothing gives a more clear indication to the Iraqis that they don't have a sovereign government” (2007). Scahill is right in pointing to the limitations of the Iraqi government's role as the ultimate authority deciding on laws on Iraqi territory. However, it does not follow that the Mansour incidence is illustrative of the extent to which the private markets for force have undermined sovereignty generally.

The Blackwater incidence usefully highlights the complex ways in which sovereignty has been both transformed and secured through the extensive privatization of the use of force. This chapter discusses this dual process of transformation and securing. It does so departing from the notion of a sovereignty game introduced by the editors which it gives a Foucauldian twist. Sovereignty in this chapter is thought of as specific form of governance, organizing politics around a central authority and working through a hierarchical and unitary system of law (Foucault 2004: 92-113; Dean 1999: 103-110). In this context the sovereignty game is a rather specific game: it is a game organized around states' claims to ultimate authority in politics. However, at the same time both sovereignty and the sovereignty game are highly variable. Politics can be (and has been) ordered around states in very many different ways. The question at the heart of this chapter is how sovereignty and the sovereignty game are rearticulated as other forms of governance develop. The answer departs from Foucault's hunch that ordering principles for politics do not replace each other but coexist historically. ${ }^{4}$ The aim is to give substance to this hunch by looking at how the coexistence of neo-liberal ${ }^{5}$ and sovereign forms of governance functions in the field of security. The chapter does this by looking at how visible and widely agreed upon changes have combined with dissimulated and denied ones to produce both profound alterations and continuity in the sovereignty game. It begins with a discussion of the rules of the sovereignty game in security and then proceeds to look at its players. ${ }^{6}$ 


\section{The Rules of the Game}

To talk about the "rules of the game" when it comes to sovereignty in the field of security - or anywhere for that matter - is a bit misleading. It suggests an inexistent precision. As Stephen Krasner has rightly insisted and repeated in all his publications: "the rules of sovereignty were not explicitly formulated in one organic package by any political leader or theorist" (2001: 249). Rather the "rules of sovereignty" are a perennial object of struggle and disagreements. However, anything does not go in the sovereignty game. At any given time those engaged in the game have an understanding of what is generally admissible or not in the game. This is why it makes sense to talk about sovereignty as an exercise in "organized hypocrisy" (Krasner 1999). Hypocrisy is only possible because there are (vague, malleable, evolving and contested) rules to be hypocritical about. The current privatization of the use of force has profoundly reshaped these rules while at the same time ensuring that the sovereignty game in the field of security can be continued.

\subsection{Visible Change: Governing security through markets}

The presence of private actors is no novelty for the sovereignty game in the security field. On the contrary, throughout the modern era states have relied on private actors when skills or men have been short in supply, or when they have had to "do dirty work" from which the state wanted to distance itself. The novelty is that markets in military services, where private actors operate independently of states, have again become acceptable. Since the end of the Cold War states have fostered markets and tried to govern security through them. They have introduced "neo-liberal" government techniques in the security sector. Decentralization, state-withdrawal, quasi-markets and the responsibilization of individuals increasingly stand in the centre of security governance. This creation of markets is a substantial change in the rules of the sovereignty game. From the midnineteenth Century onwards, the game was premised on the state monopoly on the legitimate use of force (Thomson 1994; Leander 2006: chap. 4) and on the outlawing mercenaries $^{7}$ (Percy 2007). It is now premised on the existence of markets. Lest we want to move into a brave new world lingo where monopoly and market are equivalents we need to acknowledge that this is a change. This section underscores its broad and general nature.

That markets have become central in the U.S. context is news to no one as there has been a highly public and politicized discussion around the trend. Extensive outsourcing has resulted in a situation where contractors have become indispensable to the armed forces. They provide essential logistical backup. Contractors take over "noncore tasks" - such as cooking, construction of barracks or coordination of transports that are nonetheless vital (Rasor and Bauman 2007). But also undisputedly central tasks are outsourced. This is true of intelligence (Tigner 2007; Fainaru and Klein 2007) and of an array of tasks linked to the technological "revolution in military affairs". Contractors operate unmanned (aerial, surface or sub/surface marine) vehicles that are used in combat and intelligence gathering (Zamparelli 1999; Guillory 2001; Heaton 2005). But perhaps most important for the U.S., outsourcing makes the permanent "overstretching of the armed forces" politically viable. The market is the alternative to a draft. The Pentagon official estimate is that the Armed Forces employ some 20.000-30.000 contractors in Iraq 
for 160.000 troops (Fainaru 2007c). However, this underestimates the extent to which outsourcing eases the burden on the armed forces. A Department of Defense survey estimated that some 180.000 contractors work in Iraq (Singer 2007: 2). ${ }^{8}$ Many of them work for U.S. public agencies, filling functions the public armed forces would formerly have filled themselves. The armed forces are also increasingly dependent on the international market for filling their own ranks. They hire internationally sometimes offering citizenship and/or Green Cards in exchange (Madigan 2007).

The extent to which neo-liberal forms of governance are significant also outside the U.S is likely to be less well known. In the EU, the introduction of neo-liberal governance forms in the security sector may have been slower and more discrete, but should not be underestimated. Markets govern the defense industry: "the leading European defence companies no longer operate as passive executors of government instructions.[...] As corporations seeking to survive in dynamic markets, they cannot wait until groups of politicians and military committees have deliberated over a 'Grand Plan'. In some respects, the organizational structures of European defence, and the associated attitudes, are out of line with the new corporate realities of the defence business" (Lovering 1998: 227). Similarly, just as in the U.S., the outsourcing of intelligence, the revolution in military affairs and the reliance on "dual use" and "off the shelf" technologies is placing contractors in the battlefield (Assemblée Nationale 2003). The UK created a "sponsored reserves" status for these contractors: "sponsored" by the firms who pay their salary but "reserves" within the ranks of the armed forces (Krahmann 2005). Last but not least, also the EU has a booming, private security sector whose marketization has been encouraged by the commission. ${ }^{9}$ Part of this sector holds a strong position on the international market. The most prominent firms are UK based, including firms such as Aegis or Erinys that hold major contracts in Iraq. ${ }^{10}$ But the Scandinavian countries, France and Germany also have significant private security sectors.

Finally, in the developing world outsourcing and privatization have become central government strategies. To some extent this is so because it makes defense invisible and/or more legitimate to outside creditors (Rufin 1993). But relying on markets is also necessary to fill gaps in the training and equipment of public armed forces (Howe 2001). Moreover, the market provides what allied public armed forces and states are (no longer) willing to provide. Cubic for example trains the Georgean armed forces, DynCorp the Columbian and MPRI has had a central role in providing military assistance and training in various frameworks in Africa (Paton Walsh 2004; Bigwood 2001; Singer 2003 and www.mpri.com). Third, states can reduce their defense costs by making individuals, firms, and organizations (including NGOs) who can afford to pay for their own security do so. This leads to arrangements where those who need protection hire private security providers or alternatively pay the public armed forces, or do both at the same time. Characteristically, in Sierra Leone Koidu Holdings (a mining company) pays for a contingent of public officers from the operational support division (OSD), works with the international PSC SecuricorGray and has an in-house local security division (Abrahamsen and Williams 2006: 9-10). Fourth, many states turn their armed forces into commercial ventures renting them out for multilateral operations or using them for publicly sanctioned looting (Wulf 2005). Finally, outsourcing the control over the use of force to local "private" power holders (or warlords) may be a way of upholding sovereignty at the central level. It is a strategy of state survival. Power-holders inside the 
state “mimick” warlord strategies to boost their sovereign status (Reno 1998; but also Chevrier 2004; Bayart, Ellis, and Hibou 1997).

As this shows, governing security through markets has become widespread throughout the world. The significance of this development for sovereignty is often minimized. In part because it is argued that even if there is a market states retain the "monopoly on the legitimate use of force" and in part because it is suggested that the market is not really a market but a political creation and the firms not really private but the extension of the state. Although both claims have some merit, they severely understate the significance of the changes that have taken place.

\subsection{Dissimulated Change: De-facto privatizing the legitimate use of force}

The claim that security is increasingly governed through markets is unlikely to provoke much dissent. The same cannot be said of the claim that this alters the monopoly on the legitimate use of force. Rather, states governing security through markets may face “trade-offs” (Avant 2005) and "new complexities” (Singer 2003). They may be losing control. They do not relinquish the right to define the legitimate use of force. This is true on the formal level no doubt. Legal systems (national and international) continue to be premised on that assumption. But as this section outlines this version underestimates the real degree of autonomy of the private contractors and hence masks the real degree of change in the rules of the sovereignty game.

When a market for military services is created, private actors have to be handled a direct right to decide on the use of force for rather obvious reasons. Private actors - the firms who take on contracts and their employees - have to decide when and how to use force in the context they are employed. The private security guard has to decide when to use force, as illustrated in Nisour. The intelligence contractor has a legitimate right to interpret information and sometimes to decide if it should be acted upon. For example, in Colombia the U.S. firm AirScan directed the Colombian air force to drop a cluster bomb on a village of civilians (Miller 2003). The remote controller of a UAV is using force. Just as when public armed forces use force, rules (sometimes) guide the decisions of these private actors. Sometimes (but only sometimes) there will be some form of "rules of engagement" outlining under what kind of conditions what kinds of force may be used by the private actors. Often they are as vague as those specified by the Coalition Provisional authority for contractors in Iraq starting by declaring (in capital letters) that "nothing in these rules limits your inherent right to take action necessary to defend yourself” (Fainaru 2007d). But even when they exist and are more firm, rules must be interpreted. The creation of markets turns private actors into legitimate interpreters of rules on par with public security professionals.

More controversially, firms are not only interpreters of public rules but also coauthors - and sometimes sole authors - of the rules regulating the use of force. This is the case when the rules for how, when and against whom force can be used are specified in a contract, as they often are. The centrality of contracts is linked to the contextual and varied nature of contractor activity which defies one size fits all formulations. For example, the rules specifying how a firm guarding oil installations in Ecuador (Engström 2007) may use force are bound to vary substantially from the rules specified in the 
contract covering the use of UAVs in Afghanistan (Heaton 2005: 164). But the context does not dictate the rules regulating the use of force. Firms formulate and negotiate their contracts and the "rules of engagement" specified in these. Private security firms assess security needs and suggest ways they might be filled. This is what they do when they are hired as consultants and when they advertise themselves. It is therefore not surprising that even when firms work in the same context, for similar institutions, their rules of engagement vary considerably. In Iraq, the rules of firms working U.S state agencies may vary from "contract to contract, from company to company and even from team to team" (Fainaru 2007b). Firms are in other words co-authors of the rules rather than simply accepting terms imposed by their clients (who may just as well be private as public by the way). Even more strongly, the task of formulating the rules is sometimes itself outsourced. The practice of security firms formulating (and evaluating) their own contracts has attracted substantial critical attention (Markusen 2003; Singer 2003). And even more generally, the formulation of overarching rules influencing the use of force in a given area is sometimes also outsourced to private firms. MPRI for example has considerable responsibilities for writing military doctrine and defining military training both in the U.S. and abroad (Leander 2005b, Singer, 2003, www.mpri.com ). Private firms in other words participate in the spelling out of the general rules for the legitimate use of force.

Finally, firms have a say over the legitimate use of force because they can decide whom they will work for. It is inherent in markets that buyers and sellers have a high degree of freedom when it comes to buying and selling. If they do not, we are in a command economy. This is also true in the market for force. There are rules (formal such as export controls and informal such as the normative pressure not to work for enemies of ones home government) that restrict this freedom. There may also be cartel like arrangements shaping the sale of security services in given areas. But ultimately the decision of whether to sell or not is left up to the firm. Concretely translated, private firms operating in a market for force can chose whether to work for a client, or not. They can in other words weigh - often decisively - on the decision of what kind of force will be used by whom. That is private actors legitimately control what kind of force is used in what types of situations by whom.

The privatization of the legitimate use of force is most clearly expressed in the confusion and tension surfacing whenever the formal hierarchical sovereign law system crosses the multiple, de-centered and largely informal one of the private sector. Essentially the tension and confusion concern who has the last word in deciding what specific norm applies in the given context. This confusion is sometimes resolved at gunpoint. Civil wars are examples of this: the fight is (very often) about whether the established public authority should give up its ultimate say to a private one (Holsti 1996). But also in mundane everyday occurrences involving private and public security professionals in conflict situations the conflict is sometimes dealt with at gunpoint. For example, following an accident between a SUV full of contractors and the US armed forces in Iraq, the contractors imposed their view of the situation on the soldiers by disarming them and laying them on the ground while they disentangled their SUV (Nordland, Hosenball, and Kaplow 2007). Informal pragmatic ad-hoc arrangements are another way of dealing with the tension. In Nigeria for example, Private Security Companies manage security in the oil area by coordinating a combination of private and 
public security professionals. Ultimately the hierarchy between public and private norm setters hinges on "informal arrangements and their [the PSC] capacity to develop wellintegrated procedures, joint training, and close operations coordination” (Abrahamsen and Williams 2006: 11). However, and finally, a very central way of dealing with the tensions and confusions that arise when the sovereign system crosses the neo-liberal one may be denial and/or suppression. Indeed, both firms and state officials go to considerable lengths to deny that there is a tension. That firms only work for "legitimate clients" and only against states when these are ostensibly illegitimate (i.e. to stop "the next Rwanda") are evergreens in the business rhetoric. Similarly, armed forces, defense and police administrators have a repertoire which invariably integrates the claim that governing through markets - at least in the version practiced by them - is a new (and more effective) means of achieving public ends.

Sticking to the claim that the basic rule of the sovereignty game, the state monopoly on the legitimate use of force, is intact in these conditions becomes a formalistic statement. What we have in the field of security is not fundamentally different from the situations in other areas: public and private authorities coexist in partially overlapping, competing and contradictory ways. Interesting and complex tensions are the consequence as the state system based on hierarchical relations among legal norms de facto coexists with a multi-facetted, pluri-centric complex system of private rules defying both unity and hierarchy (Fischer-Lescano and Teubner 2004). This said, the illusion that the rules of the sovereignty game remain intact, that states retain a monopoly on the legitimate use of force is of considerable practical significance: it masks part of the fundamental change in the rules of the sovereignty game brought about by privatization. By the same token it effectively blocs broader political discussions about this change and its desirability. It is a form of "symbolic power" (Bourdieu 1992). The change in rules of the game can pass unnoticed and be presented as a mere variation on existing themes.

\subsection{Securing the sovereignty game in security}

Securing the continued centrality of sovereignty in the field of security is about more than dissimulating change and preempting public debate. The centrality of sovereign practices in security has also been positively bolstered and confirmed by the introduction of markets. The transformation of governance processes in security - the shift towards neoliberal governance techniques where outsourcing, privatization, responsibilization, decentralization and state withdrawal are central - makes security governance congruent with governance in other spheres. Since these changes are framed as changes in (rather than contra) sovereignty, they have helped legitimate and perpetuate the sovereignty game.

Today it is easy to forget the extent to which the sovereignty game in security was under pressure in the wake of the Cold War. The question at the time was if the world was headed towards Gorbachov's “new world order” where security and particularly military relations would have a far less central place. In sociology authors talked about the post-military society (Shaw 1991). In international relations attention was increasingly directed towards globalization and the retreat of the state while security discussions focused on the necessary transformation (and slimming) of existing state based defense institutions (Clark 1999). The consequence was that these were under very real pressure to justify their own existence and had to scramble with decreasing budgets 
expressing their low ranking on the list of public priorities (Schméder 1998; Bigo 2000). At the end of the Cold War the future prospects of the sovereignty game in security seemed dim on most accounts. This is no longer the case, for reasons closely tied to the transformations at the heart of this chapter: the introduction of governance through markets justified and normalized the sovereignty game. The end of the Cold War caused the crisis of the sovereignty game and triggered the processes that ensured its continuation.

It did so by making the governance of security congruent with governance in other fields. The end of the Cold War signaled an end to the politically motivated strict state control over anything military related. Managing the military, the police and security through markets became imaginable. The "neo-liberal revolution" with the accompanying new public management could be extended also to the defense sector (Brauer 1998; Bislev, Hansen, and Salskov-Iversen 2002; Minow 2003). Market competition and "post-Fordism" could be introduced. The state could withdraw. Firms were asked to fend for themselves, dispensing with subsidies and controls (Kaldor 1998). Citizens were increasingly expected to take responsibility for their own security. At the same time, the decreasing willingness to pay for armed forces put pressure on armed forces and states to draw on the rapidly developing markets. As a consequences of these shifts in governance forms, the security field no longer appeared as an anachronistic field, the only one still governed by old style, top-down state bureaucracies. As in other fields, the expertise and knowledge of a wide range of autonomous private actors could now be integrated in the policy process. A language of market and effectiveness could make sense of the activities in the field. The security field could be governed by the same neoliberal techniques as other fields of society.

The extent to which this helped justify activity in the field is perhaps best seen in the willingness of security professionals, administrators and policy-makers linked to defense establishments to embrace reforms. Indeed, the new public management reforms had the effect of increasing resources. This is not primarily linked to private firms and markets being cheaper and more effective and hence improving the use of existing resources. The call is still out on whether privatization in the security field actually leads to any efficiency and financial gains. Impressive potential gains from privatization coexist with an actual history of enormous waste and ineffectiveness. ${ }^{11}$ The point rather is that for officials governance through markets increases the resources available. Partly, for banal accountancy reasons: governing through various forms of markets, sub-contracting and outsourcing activities diverts spending from main budgets. It makes the actual resources used in a field less visible and more difficult to scrutinize. But partly, the reason to embrace NPM in security is the political and social context: privatization and market creation have become policy-making priorities. Money spent to buy services and equipment in markets is de facto judged by different (more generous) criteria than money on public services. The reliance on private markets and firms is justified in and of itself (Markusen 2003).

The creation of private markets of security profoundly alters the rules of the sovereignty game: it ends the monopoly on the legitimate use of force on which this game rested. However, at the same time it secures the game. Sovereign governance forms in security are shown to be perfectly compatible with neo-liberal forms of governance and hence to be similar to sovereign forms of governance in other spheres. At the same 
time a formalistic attachment to the ultimate say of the state in matters of legitimate use of force masks the change that is entailed. The rules of the sovereignty game on this account have undergone profound change that has served to consolidate the centrality of sovereign practices.

\section{The Players in the Game}

Governing security through markets is also having profound effects on the players in the sovereignty game in security. Private actors are increasingly present in field sometimes ostensibly on par with states. As the modern sovereignty game is played by states, one might have expected such challenges to their centrality to make the game meaningless and/or unimportant. Yet, nothing of the sort has happened. The reason is partly that the enmeshment of the private and the public spheres has made the public private and the private public, hence obscuring the growing centrality and presence of private actors. In addition to this, when private actors have been ostensibly visible, they have mostly not been taken to challenge the sovereignty. Rather, their presence has been interpreted as illustrating the need to differentiate among states who can manage markets and states still having to learn. This combination of enmeshment and unequal status of sovereign players has distracted attention away from conflicts and tensions that might have arisen between public and private actors. It has concentrated conflicts around divisions within states and divisions between Northern and Southern states. Both forms of conflicts are compatible with a sovereign ordering of politics and can be read as confirming its continued centrality.

\subsection{Dissimulated change: The enmeshment of public and private}

In the stylized world of political and legal thought, the private/public, inside/outside and state/market realms are distinct spheres with clear dividing lines. However, the world of political practice looks rather different. The spheres are largely continuous realms as indicated by the omni-present reference to "blurred" lines. But the reference to blurred lines assumes distinct realms whose dividing lines can blur. In the security field, governance through markets is making this situation increasingly rare. At all levels and in all kinds of functions, there are many people who are in both spheres at the same time. It is more therefore accurate to think of the spheres as enmeshed. This enmeshment is important for the stabilization of the sovereignty game as it bolsters the impression that public actors continue to rule unchallenged by private market actors. By dissimulating the change in the nature of the public actors, it ensures the continuity of the sovereignty game.

The security professionals working in the rapidly expanding market are mostly members of the armed forces and the police. Everyone is an ex-something (Singer 2003). Those with special skills, from elite troops of one kind or another, have been particularly sought after as the 15.000 or so false Navy SEALs testify (Lee Lanning 2002: 176). Blackwater pays six times more than the U.S armed forces for military qualifications at an equivalent level. But it is not the only American firm to pay more than the public armed forces or the police, nor is the situation unique to the U.S. Also in Nigeria, Russia or Columbia, working for a private security company is an attractive way of complementing a low salary or pension, in addition to being an opportunity to get 
interesting work. ${ }^{12}$ These professionals very often keep their jobs also in the public sector hence embodying the continuity between public and private spheres. Since the market is increasingly "global", the security companies for whom professionals work may well take them abroad. Hence, an unknown number of security professionals form Africa, Latin America and Asia have worked on contracts in Iraq embodying the continuity between the national and the outside. ${ }^{13}$ Finally, private actors on the battlefield embody the continuity between the state and the market spheres. In Iraq, in the DRC and in Afghanistan the private security professionals engaged in a conflict are often undistinguishable from soldiers, for many civilians, for those on the opposing side and for military field commanders who integrate them into their understanding of the battlefield situation (Verkuil 2007: 27).

Also on the management side, the number of people whose existence is simultaneously on both sides of the public-private line is rapidly growing. Many managers work in both the public and the private sectors at the same time. Firms are often set up and organized by people with a past in the public. Sometimes they formally continue to work in the public taking a leave while running their private firm. When this is not the case they maintain close contacts to the public administration and often see themselves as merely continuing their (public) job from "the other side of the table". To add to this, private security sector firms routinely hire high-ranking policy-makers on their boards. Cheney epitomizes this trend (Didion 2006). But Cheney is no unique example. Many firms have board members who are at the same time active policymakers. This is more than a revolving-door policy. It is a simultaneous presence. It may be worth underlining that it is not a U.S. specific phenomenon but one visible across different contexts and continents (Joly 2003; War on Want 2006; Akeh 2007). At least as significant as the presence of public officials in the private, but far less noticed, is the presence of the private in the public. The markets have entered public administrations and become integral parts of these. The Pentagon counts the contractors in to the total U.S. war effort. But it is not the only place where markets are represented inside states. Public officials have come to rely on market actors, work for them and believe in the fact that "with contractors you get more bang for the buck" (Whelan 2003). In many contexts they also depend on the market for financing their own activities. For example in Ecuador, the private security sector indirectly finances the public armed forces: they have to rent the police force for any operation involving the use of weapons (Engström 2007).

This presence of the public in the private and the private in the public is really a matter of enmeshment. It does not signal the swallowing up or cooptation of one sphere by the other. To reduce the private firms to extensions of public policy is to misunderstand them. They may work for public agencies and authorities but their existence is not reducible to this. They also have an existence as market actors striving to make money and capture market shares. This is why Eric Prince (the CEO) of Blackwater insists in his Congressional hearing that "we are a private company and the key word is private" (2007). It is also important to realize that it is because they are private and autonomous that the private firms are valued by public administrations. Their independent expertise is often what is sought. It would be equally mistaken to reduce the public to the private, suggesting for example that policy-makers working in the private sphere are only private actors, following firm interests and somehow shred their "public" identity and values even if they continue to hold public office. Whether they are security 
professionals or policy-makers they retain also a public identity. This is the reason enmeshment is an adequate term for the situation: it captures the extent to which what is happening is neither a blurring of lines between distinct spheres nor simply a matter of cooptation or corruption of one by the other but a growing presence of the two spheres inside each other.

While this enmeshment signals real change both in who matters for security and in the nature of the public, it stabilizes the sovereignty game in the field of security. It obscures the extent to which states now share their central role in security with private market actors, that is the degree to which the actors of the security game have changed. It also obscures the extent to which the nature of the public itself has been altered and become enmeshed with market the private. Enmeshment lends credibility to the stretching of the category of the public which comes to cover also the activities of private firms. It is in other words essential for reducing the visibility of private actors in the security field.

\subsection{Visible change: From equality to empire}

There are many situations where the centrality of private actors in the security field is difficult to ignore. Yet, the sovereignty game seems largely unaffected by this visible emergence of private actors. It proceeds as if public actors were still the uncontested key actors. This is rather intriguing. The drift away from the equal treatment of the players in the sovereignty game is the clue to the magic that makes the intrigue work. By defining states who cannot prevent private actors from being visible as "failed" and by denying them the status as full sovereign players, the emergence of private actors can be treated as a marginal phenomenon to be handled by the ever more intrusive "capacity building" policies of fully sovereign states.

Enmeshment only works if the role of private activity can credibly be understood as something falling within the category of things undertaken by the public. This is not the case when private actors are too sharply separated from and/or defined by contrast to the state. Illustrations of this include security provision by "war lords" or "big men" (Derlugian 2005). More mundanely it includes the many situations where vigilantes (Buur 2006), hunters' associations (Bassett 2003) or (reinvented) tribal protection systems (Heald 2007; Nolte 2007) are central for the provision of security. These private actors are often authorized and encouraged by states and can hence be read as expressing new forms of sovereign authority. But it is not an authority that can somehow easily be presented as "public" in the sense of being part of the state or drawn into an enmeshed public - private continuity. Enmeshment also fails when states are "privatized", when public officials act ostensibly mainly for private gain and are seen as doing precisely that. This is the case for example when heads of states use their own "private" armies as commercial ventures for the exploitation of private resources (UN 2001) or when members of the public armed forces act purely for personal gain as is the reputation of Nigeria's mobile (armed) police units going under the nickname "kill and go" (Abrahamsen and Williams 2006: 3). These situations have in common that there is no public category that could credibly mask the presence and role of private actors.

There is good reason to think that the emergence of situations where private actors have a visible place in the security field has much to do with the neo-liberalization 
of security governance. ${ }^{14}$ However, states, not markets, are usually held responsible for the visibility of private security actors. They are differentiated according to whether or not they can handle the private market development. On this account, it is because certain states do not have the "capacity" to deal with their internal security situation that private actors are emerging as central in the security field. Echoing the focus on "capacity building” in other areas and its dominance in the thinking of most relevant (state, multilateral and non-governmental) institutions, building capacity to control security becomes essential. At the same time, the security sector is overtaking other fields as the conventional assumption that development would create security is being replaced by the inverse assumption: that security is a precondition for development (Buur, Jensen, and Stepputat 2007; Duffield 2007). Development aid is consequently channeled from traditional development areas (infrastructure, health and education) into the security where it is used to facilitate capacity building in the security sector. Hence the rapidly growing interest in security sector reform.

For the sovereignty game, the responsibilization of states translates into a differentiation among the sovereign players. States are no longer just states. They are states with qualifiers such as quasi, failed, weak, or rogue underlining their incapacity to control private actors and the market for force on their territories. These qualifiers have a bearing on the practical meaning of the sovereign status. Some states find themselves in an uphill struggle trying to defend their status as sovereign players even if private actors are indeed visible (e.g. Columbia, Georgia, Sudan). Others, deemed too failed or rogue to deserve to be recognized as sovereign states, may find their position and role as sovereigns players eliminated altogether as for example when a consortium of international donors and institutions take on the management of sections of the Chadian economy through their control over the Chad-Cameroon pipeline, when Ethiopia restores order in Somalia or when international supervisors are allocated to the key ministries in Monrovia. This relativization of the sovereign status is intensely contested. However, the trend is there. The qualifiers have made their way into the language policy-making communities, the media and academia alike. The same is true of the idea that in cases of extensive human rights violations and/or threats to international stability "major states or regional or international organizations could assume some form of de facto trusteeship" (Krasner 2004: 119; also Ehrenreich Brooks 2005). The idea that differentiated sovereignty justifies outside tutorship is not "new" on a broader historical scale (as Krasner has repeatedly pointed out). It has analogies in the eighteenth and nineteenth centuries. However, viewed from the vantage point of twentieth century decolonialization struggles (and achievements) it is a remarkable reversal to imperial argumentation (Bishai 2004).

The visible, resisted and contested move from an egalitarian to an imperial understanding of the status of sovereign players has helped securing the central role of states in the game. It has normalized the idea that if and when private actors do play an ostensibly central role in the security field, this does not challenge the centrality of states in general. It merely underlines the need to distinguish among the players in the sovereignty game and to support (or impose) capacity building in weaker states. The shift from an egalitarian to an imperial discourse on the nature of sovereignty has made it plausible both to acknowledge the presence of private actors in the security field and to deny their significance for the sovereignty game. 


\subsection{Securing the centrality of sovereign states as players}

The enmeshment of public and private and the shift from an egalitarian to an imperial discourse have helped secure the sovereignty game by obscuring the extent to which there is change in the nature of the key players (they are no longer clearly public) and in their roles (they are no longer formally equal). However, the two processes have also played an important role in another way: they have prevented conflicts and tensions that stem from the emergence of the market to become crystallized around the public-private divide. By so doing they have bolstered the impression that the market alters nothing fundamental about the public - private divide and that markets are therefore perfectly compatible with sovereignty. It has confirmed the compatibility of neo-liberalism and sovereignty in the security sphere.

A direct consequence of placing the private in the public and the public in the private is that conflicts and disagreements stemming from the rise of markets are not structured as conflicts opposing private and public actors. Instead conflicts are structured around divisions within the public and within the private. In the U.S. for example, the issue of security privatization has to some extent opposed Democrats and Republicans. Although the Clinton administration endorsed the general outsourcing and market creating policies, the key opponents (including in particular Senator Jan Schakowski ${ }^{15}$ ) have been Democrats and key proponents (including Cheney and Rumsfeld) have been Republicans. But divisions along party lines are too rough. The divisions run between public administrations and - on and even more detailed level - between individuals; often in rather unexpected ways. The investigation in the wake of the Nisour incident clearly illustrates this. In Iraq the State Department had sided in with Blackwater against other authorities and in particular the justice department (Committee on Oversight and Government Reform 2007). Similarly, the Inspector General had obstructed the work of his office and refused to collaborate with the Department of Justice in investigations involving security contractors (Waxman 2007). Conflicts and tensions resulting from the creation of markets in security in other words do not pit private market actors against public state actors. They create new divisions within states. Conflicts are opposing different parts of states and public bureaucracies. They are not state versus market conflicts. For the sovereignty game this matters: it confirms that what is at stake is not some fundamental reshuffling of authority but merely more of the good old struggle over what the aim of public policy should be and how it can best be achieved; a struggle reflecting diverging expert views. This is something the sovereignty game has always lived with.

Similarly, the way qualifiers to statehood and sovereignty have developed and been used has minimized the extent to which conflicts surrounding the emergence of markets come to be structured along the private - public divide. The flat responsibilization of (failed, rogue, weak etc.) states and governments for their failure to keep private actors invisible is a direct denial of the role that the market or market actors may have played in the process. But more than this, the qualifiers direct attention to the North - South divide, and away from the division between the public and the private. The states with qualifiers are overwhelmingly Southern and those using the qualifiers to differentiate sovereign status and justify interventions are overwhelmingly Northern. Consequently, and colonial pasts helping, the conflicts surrounding the introduction of qualifiers readily turn into North - South conflicts. In the confrontation over qualified 
sovereign status, the image of a self-sacrificing, humanitarian, civilizing North contributing to the development in the South confronts that of the destructive, exploiting, self-interested North sapping the independence and development prospects of the South. The point here is not to adjudicate which of these images is more truthful. Rather, the purpose is to underscore the extent to which this North - South framing casts the dispute in terms that can be used to confirm the centrality of states in the sovereignty game; the conflict is ultimately about diverging sovereign interests.

The conflict has been transformed from one where public actors might have opposed the creation of markets into one where sovereign states with differing and sometimes radically opposed interests confront each other. The confrontation is turned into a clash of sovereignties. A classical picture of what the sovereignty game is all about. The same trick is worked by the enmeshment of actors: it turns the conflict into one taking place within states, opposing divergent different understandings of how best to promote the public good, a classical conflict in sovereign forms of politics. Conflicts that might have arisen as private actors have taken on a central role in security and could have been thought to challenge the key role of public actors magically disappear. They are transformed into conflicts that do not challenge sovereignty as the main ordering principle in the field. If anything, the continuation of intense conflict over what policies to pursue at home and over clashing sovereignties abroad confirms sovereignty's continued significance.

\section{Conclusion: Securing Sovereignty}

This chapter has argued that the governance of security through markets has been the source both of substantial changes in the sovereignty game and of the securing of game. Market governance has altered the basic rule of sovereignty game in securit, watering down the state monopoly on legitimate force to inexistence. Private actors have both control and legitimate authority over the use of force. Market governance has also altered the nature and the status of the players in the sovereignty game as the public and private have become increasingly enmeshed and sovereignty increasingly differentiated. However, at the same time governance through markets has secured sovereignty. It has aligned the sovereignty game in security with neo-liberal governance forms. It has normalized security. But more than this the effects of market governance on the nature of the public/private divide has fostered misrecognition of the changes under way. As a consequence the sovereignty game in security, recast in governmental terms, is well secured, probably at least as secure as it would have been if market governance had not been introduced.

That profound change in the sovereignty game may be compatible with (perhaps even necessary for) its continuity is not a foregone conclusion. Scholars who think of sovereignty as a specific set of principles would certainly find it difficult to agree. Thomson for example suggests that if practices changed so much that states could "shirk responsibility for non-state violence internationally, by simply claiming that the latter is a purely private undertaking" and "if there was an "end to or at least significant erosion of the state's monopoly on the authority to deploy violence beyond its borders" we would be shifting away from sovereignty to something else (Thomson 1994: 153). This chapter has suggested that both things are occurring but we have not moved away from sovereignty 
to something else. The reason is that sovereignty (and the sovereignty game) is not attached to a specific set of rules but one way of organizing political thinking and practice. This mode may well coexist (as I have here argued it does) with other forms of governance such as the neo-liberal or the disciplinary. This will cause clashes and tensions. It will not "end" the sovereignty game. The game ends when political practice and thinking ceases to be organized around states; when the king's head is finally cut in political theory and practice as Foucault phrased it. Governing through markets has not led this to happen. If anything the opposite is true.

But for how long is sovereignty secure? Is the market working like a time bomb that will eventually explode the sovereign system and lead to the dissolution of state authority (as suggested e.g. by von Trotha 2000)? Or will the tensions between the governance through markets and governance through states eventually become so strong that states will have to rein in the market and reassert political control (as suggested by Verkuil 2007)? Obviously, there can be no definitive answer. However, three observations drawn from this chapter may be worth keeping in mind when contemplating the question. First, the sovereignty game is surprisingly resilient and malleable. It is a grid of practice and interpretation that is difficult to escape. Second, (however) neoliberal forms of governance are so profoundly anchored in contemporary political practice and thinking that they pass largely uncontested, not to say unreflected. Third, (this said) how the two coexist is neither strictly fixed nor agreed upon. It is constantly struggled over. We are therefore likely to see market governance and sovereignty continue to coexist, create tensions but also reinforce each other in surprising ways expressing the constant struggles over those concerned by the developments. 
References

Abrahamsen, Rita, and Michael C. Williams. 2006. The Globalization of Private Security: Country Report Nigeria. Aberystwyth: University of Wales. . 2006. The Globalization of Private Security: Country Report Sierra Leone. Aberystwyth: University of Wales.

Akeh, J.M.Migai. 2007. Breaking the Cartel of Power: Democracy, Public Law Values, and the Governance of Privatization in the Weak State in Africa. Manuscript Nairobi.

Assemblée Nationale, France. 2007. Loi n 2003-340 du 14 avril 2003 relatif à la répression de l'activité de mercenaire. Assemblée Nationale, France 2003.

Avant, Deborah. 2005. The Market for Force: The Consequences of Privatizing Security. Cambridge: Cambridge University Press.

Bassett, Thomas J. 2003. Dangerous Pursuits: Hunter Associations (Donzo ton) and National Politics in Cote D'Ivoire Africa: Journal of the International African Institute 73 (1):1-30.

Bayart, Jean François, Stephen Ellis, and Béatrice Hibou. 1997. La criminalisation de l'Etat en Afrique. Paris: Editions Complexe.

Bigo, Didier. 2000. When two become one: Internal and external securitisations in Europe. In International Relations Theory and the Politics of European Integration. Power, Security and Community, edited by M. Kelstrup and M. Williams. London and New York: Routledge.

Bigwood, Jeremy. 2001. DynCorp in Colombia: Outsourcing the Drug War. www.corporatewatch.org, 23 March.

Bishai, Linda. 2004. Liberal Empire. Journal of International Relations and Development 7 (1):48-72.

Bislev, Sven, Hans Krause Hansen, and Dorte Salskov-Iversen. 2002. The Global Diffusion of Managerialism: Transnational Discourse Communities at Work. Global Society 16 (2):199-212.

Bourdieu, Pierre. 1992. Language and Symbolic Power. Cambridge: Polity Press.

Brauer, Jürgen. 1998. An Economic Perspective on Mercenaries: Military Companies and the Privatisation of Force. Cambridge Review of International Affairs XIII (1):130-146.

Buur, Lars. 2006. Reordering society: Vigilantism and sovereign expressions in Port Elizabeth's townships. Development and Change 37 (4):735-757.

Buur, Lars, Steffen Jensen, and Finn Stepputat, eds. 2007. The Security-Development Nexus. Capetown: HSRC Press.

Chevrier, Yves. 2004. Postface: Privatisation and the Historical Paths of the Political. In Privatizing the State, edited by B. Hibou. New York: Columbia University Press.

Clapham, Christopher. 1996. Africa and the International System. The Politics of State Survival. Cambridge: Cambridge University Press.

Clark, Ian. 1999. Globalization and International Relations Theory. Oxford: Oxford University Press.

Committee on Oversight and Government Reform. 2 October 2007. Hearing: Private Security Contracting in Iraq and Afghanistan.

- 2007. Memorandum to the Members of the Committee on Oversight and Government Reform: Additional Information about Blackwater. 
Dean, Mitchell. 1999. Governmentality, Power and Rule in Modern Society. London: Sage.

Derlugian, Georgi. 2005. Bourdieu's Secret Admirerer in the Caucasus. A World System Biography. Chicago: Chicago University Press.

Didion, Joan. 2006. Cheney: The Fatal Touch. New York Review of Books 53 (15).

Dorn, Nicholas, and Michael Levi. 2007. European Private Security, Corporate Investigation and Military Services: Collective Security, Market Regulation and Structuring the Public Sphere. Policing \& Society 17 (3):213-238.

Duffield, Mark. 2001. Global Governance and the New Wars. The Merging of Development and Security. London and New York: Zed Books.

- 2007. Development, Security and Unending War: Governing the World of Peoples. Oxford: Polity Pres.

ECJ. 2006. C-514/03 Commission v Spain: European Court of Justice.

Ehrenreich Brooks, Rosa. 2005. Failed States or the State as Failure? University of Chicago Law Review 71 (4):1159-1196.

Engström, Agneta. 2007. Ecuador: Oil and Militarized Corporate Terrorism. Upside Down World 14 November.

Fainaru, Steve. 2007a. For abducted guards, Iraq wasn't about money. Washington Post, 30 September.

— 2007b. Guards in Iraq Cite Frequent Shootings; Companies Seldom Report Incidents. Washington Post, 3 October.

2007c. Iraq Contractors Face Growing Parallel War. Washington Post, 16 June.

- 2007d. Where military rules don't apply. Washington Post, 20 September.

Fainaru, Steve, and Alec Klein. 2007. In Iraq, a Private Realm of Intelligence Gathering. Washington Post, 1 July.

Fischer-Lescano, Andreas, and Gunther Teubner. 2004. Regime-Collisions: The Vain Search for Legal Unity in the Fragmentation of Global Law. Michigan Journal of International Law 25:999-1045.

Foreign and Commonwealth Office. 2002. Private Military Companies: Options for Regulation. London: http://www.fco.gov.uk/Files/kfile/mercenaries,0.pdf.

- 2002. Response of the Secretary of State for Foreign and Commonwealth Affairs to the Ninth Report of the Foreign Affairs Committee: Private Military Companies (session 2001-2002): http://www.fco.gov.uk/Files/kfile/cm5642.pdf.

Foucault, Michel. 2004. Sécurité, territoire, population. Cours au Collège de France (1977-1978). Paris: Gallimard, Seuil.

GAO. 2007. Defense Budget: Trends in Operation and Maintenance Costs and Support Services Contracting. Washington: United States Government Accountability Office.

Guillory, Major Michael E. 2001. Civilianizing the Force: Is the United States Crossing the Rubicon? The Air Force Law Review 51:111-142.

Heald, Suzette. 2007. Controlling Crime and Corruption from Below: Sungusungu in Kenya. International Relations 21 (4):183-199.

Heaton, J. Ricou. 2005. Civilians at War: Reexamining the Status of Civilians Accompanying the Armed Forces. Air Force Law Review 57:157-208. 
Hibou, Béatrice. 2004. From Privatising the Economy to Privatising the State: An Analysis of the Continual Formation of the State. In Privatizing the State, edited by B. Hibou. New York: Columbia University Press.

Hindess, Barry. 2004. Liberalism - What's in a Name? In Global Governmentality: Governing International Spaces, edited by W. Larner and W. P. Walters. London: Routledge.

Holsti, Kalevi J. 1996. The State, War, and the State of War. Cambridge: Cambridge University Press.

Howe, Herbert M. 2001. Ambiguous Order: Military Forces in African States. Boulder CO.: Lynne Rienner.

Joly, Eva avec la contribution de Laurent Beccaria. 2003. Est-ce dans ce monde-là que nous voulons vivre? Paris: Editions des Arènes.

Kaldor, Mary. 1998. Introduction. In Restructuring the Global Military Sector: New Wars, edited by M. Kaldor and B. Vashee. London: Pinter.

Krahmann, Elke. 2005. Controlling Private Military Companies in the UK and Germany: Between Partnership and Regulation. European Security 13 (2):277-295.

Krasner, Stephen D. 1999. Sovereignty: Organized Hypocrisy. Princeton: Princeton University Press.

. 2001. Abiding Sovereignty. International Political Science Review 22 (3):229251.

—. 2004. Sharing Sovereignty: New Institutions for Collapsed and Failed States. International Security 29 (2):85-120.

Leander, Anna. 2005a. The Market for Force and Public Security: The Destabilizing Consequences of Private Military Companies. Journal of Peace Research 42 (5):605-622.

— 2005b. The Power to Construct International Security: On the Significance of Private Military Companies. Millenium Journal of International Studies 33 (3):803-826.

- 2006. Eroding State Authority? Private Military Companies and the Legitimate Use of Force. Rome: Centro Militare di Studi Strategici.

— 2007. Re-Configuring Security Practices: On the Power of the Private Security Business. CBS Working Paper.

Leander, Anna, and Rens van Munster. 2007. Private Security Contractors in Darfur: Reflecting and Reinforcing Neo-Liberal Governmentality. International Relations 21 (2):201-216.

Lee Lanning, Michael. 2002. Blood Warriors: American Military Elites. New York: Presidio Press.

Lovering, John. 1998. Rebuilding the European Defense Industry in a Competitive World. In Restructuring the Global Military Sector. The End of Military Fordism, edited by M. Kaldor, U. Albrecht and G. Schméder. London and Washington: Pinter.

- 2000. Loose Cannons: Creating the Arms Industry of the Twenty-first Century. In Global Insecurity, edited by M. Kaldor. London: Pinter.

Madigan, Nick. 2007. 13 People Taking the Oath of Allegiance at Fort McHenry had served their country even before it was their country. Baltimore Sun, 25 September. 
Markusen, Ann R. 2003. The Case against Privatizing National Security. Governance: An International Journal of Policy, Administration, and Institutions 16 (4):471-501.

Miller, Christian. 2003. U.S. pair's role in bombing shown. Los Angeles Times, 16 March. Minow, Martha. 2003. Public and Private Partnerships: Accounting for the New Religion. Harvard Law Review 116 (March):1229-1270.

Nolte, Ina. 2007. Ethnic Vigilantes and the State: The Oodua People's Congress in SouthWestern Nigeria International Relations 21 (4):217-235.

Nordland, Rod, Mark Hosenball, and Larry Kaplow. 2007. Blackwater is Soaked: An Arrogant Attitude Only Adds Fuel to the Criticism. Newsweek, 15 October.

Paton Walsh, Nick. 2004. US Privatizes its Military Aid to Georgia. The Guardian, 6 January.

Percy, Sarah. 2007. Mercenaries: Strong Norm, Weak Law. International Organization 61 (2):367-397.

Rasor, Dina and Robert Bauman. 2007. Betraying Our Troops: The Destructive Results of Privatizing War. New York: Palgrave.

Reno, William. 1998. Warlord Politics and African States. Boulder, London: Lynne Rienner.

Rose, Nikolas and Peter Miller. 1992. Political Power Beyond the State: Problematics of Government. British Journal of Sociology 43 (2):173-202.

Rufin, Jean-Christophe. 1993. Les économies de guerre dans les conflits internes. In Économie des guerres civiles, edited by F. Jean and J.-C. Rufin. Paris: Hachette.

Sapone, Montgomery. 1999. I have rifle with Scope, will travel: The Global Economy of Mercenary Violence. California Western International Law Journal 30 (fall):143.

Scahill, Jeremy. 2007. Blackwater: The Rise of the World's Most Powerful Mercenary Army. Washington: Nation Books. 2007. Out in the Open: CNN 24 September 8:00 PM EST.

Schméder, Geneviève. 1998. Global Trends in Military Efforts and Activities. In Restructuring the Global Military Sector. The End of Military Fordism, edited by M. Kaldor, U. Albrecht and G. Schméder. London and Washington: Pinter.

Shaw, Martin. 1991. Post-Military Society: Militarism, Demilitarization and War at the End of the Twentieth Century. Cambridge: Cambridge University Press.

Singer, Peter W. 2003. Corporate Warriors. The Rise of the Privatized Military Industry. Ithaca and London: Cornell University Press.

— . 2007. Can't Win with 'Em, Can't Go to War without 'Em: Private Military Contractors and Counterinsurgency. Foreign Policy at Brookings. Policy Papers (4).

Thomson, Janice. 1994. Mercenaries, Pirates, and Sovereigns: State-building and Extraterritorial Violence in Early Modern Europe. Princeton: Princeton University Press.

Tigner, Brooks. 2007. Intelligence: The Risks of Going Private. ISN Security Watch, 3 April.

UN. 2001. Report of the Panel of Experts on the Illegal Exploitation of Natural Resources and Other Forms of Wealth of the Democratic Republic of Congo (S/2001/357). New York: UN Security Council. 
UN, General Assembly. 2007. Report on the question of the use of mercenaries as a means of violating human rights and impeding the exercise of the right of peoples to self-determiniation (A/62/150). New York: UN.

Verkuil, Paul. 2007. Outsourcing Sovereignty: Why Privatization of Government Functions Threatens Democracy and What We Can Do about It: Why Privatization of Government Functions ... Democracy and What We Can Do About It. Cambridge: Cambridge University Press.

von Trotha, Trutz. 2000. Die Zukunft liegt in Afrika. Leviathan 28:253-279.

War on Want. 2006. Corporate Mercenaries. London: War on Want.

Waxman, Henry. 18 Sept. 2007. Letter to the Inspector General, Honorable Howard J. Krongard,on Behalf of the Committee on Oversight and Government Reform. Washington: Congress of the United States.

Whelan, Theresa. 2003. (Deputy Assistant Secretary of Defense for African Affairs) Remarks to IPOA Dinner. Washington D.C. 19 Nov. 2003.

Wulf, Herbert. 2005. Internationalizing and Privatizing War and Peace. Basingstoke and New York: Palgrave.

Zamparelli, Colonel Steven J. 1999. Competitive sourcing and privatization: Contractors on the battlefield. Air Force Journal of Logistics XXIII (3):1-17.

Zedner, Lucia. 2006. Liquid Security: managing the market for crime control. Criminology and Criminal Justice 6 (3):267-288. 


\section{Notes:}

${ }^{1}$ This chapter has benefited from the generous and constructive comments of the editors of this volume. Moreover, Stefano Guzzini and the participants in the COSTA24 seminar on the private construction of threats (Basel 20 October 2007), in my fellow-seminar at the Hansewissenschaftskolleg (17 October 2007) and in the DIIS “markets for peace” workshop (6-7 December 2007) made helpful comments. Even if they would all still have many objections to this version of the chapter, I hope that they recognize their role in sharpening its argument which obviously remains my responsibility.

${ }^{2}$ At the time of writing (November 2007) it seems the state department will end Blackwater's Iraq contract after considerable pressure but the process is still ongoing and whether or not there will be any general consequences for Blackwater (preventing it from working on other state contracts) remains unclear.

${ }^{3}$ Jeremy Scahill is the author of a book on Blackwater that launched much of the media attention the company has received and an active media commentator (2007).

4 "There is no historical replacement of historical form [...] There is in fact a triangle: sovereignty, discipline and governmentality” (Foucault 2004: 111).

${ }^{5}$ The Foucauldian use neo-liberal government techniques has much in common with what goes under the general heading "new public management". It is the idea that governance is done through state withdrawal, the creation of quasi-markets, decentralization, and responsibilization of individuals (Foucault 2004;

Hindess 2004; Rose and Miller 1992; Leander and van Munster 2007).

${ }^{6}$ There is also profound change in the stakes of the game: technical security is more central both in the security field and in other fields For reasons of space this point is not elaborated in this chapter. I have written about it elsewhere including in (Leander 2005b, 2007)

${ }^{7}$ Today the term mercenary is increasingly replaced by words coming with less negative connotations such as contractors, private military firms, or private security firms. This masks the similarities between these actors and traditional mercenaries. It helps obscure the changes taking place.

${ }^{8}$ The figures remain very uncertain though even for contractors employed by firms working for public U.S. agencies and even more so for other firms. They are particularly unreliable for "third country nationals", "local" employees, and sub-contractors working for the main contractor. Judging from the controversies that have involved South African, Korean, Pilipino, Ugandan, Tanzanian, Peruvian, Fijian, Columbian and Nepalese (just to mention some) security contractors their numbers could be rather extensive.

${ }^{9}$ In a succession of controversial cases the commission has pushed for the opening of the market. See ECJ (2006) and the references therein as well as Dorn and Levi (2007).

${ }^{10}$ In its discussions of regulation, the UK government has repeatedly made very clear that it sees the sector is to be nurtured and developed nationally and internationally (Zedner 2006; Foreign and Commonwealth Office 2002, 2002).

${ }^{11}$ There is no proof that outsourcing is efficient but considerable indications that it is not: Markusen (2003), GAO (2007), Waxman (2007), Rasor and Bauman (2007), and Verkuil (2007). These indications are bolstered by the resistance of the business against actual measures designed to enhance cost savings in the sector. In 2001 e.g. DynCorp blocked a bill that would have forced federal agencies to justify private contracts on cost-saving grounds (War on Want 2006: 19).

${ }^{12}$ Security professionals' motives are complex and varied but interest in working actively often figures at least as centrally as earning a good salary (Sapone 1999; Fainaru 2007a).

${ }^{13}$ This practice is most visible when scandals erupt around illegal recruitments or breaches of contract by international firms. The OHCHR working group on mercenaries has made an effort to report on some of the scandals in a more systematic fashion (UN 2007).

${ }^{14}$ The pressure on budgets, the forced dissolution of "neo-patrimonial" systems and the opening up of markets weakens state institutions in the security field and forces those who want protection to look for it outside the state, in new arrangements. At the same time it pushes security professionals to engage in the market (Clapham 1996; Duffield 2001; Hibou 2004; Leander 2005a).

${ }^{15}$ Jan Schakowski has a long standing engagement with the issue of security contracting and has proposed a series of bills to curb contracting practices, including the recent SOS (stop outsourcing security) the fate of which remains as uncertain as that of her earlier initiatives. 